\title{
Long-term Shifts of Chum Salmon (Oncorhynchus keta) Distribution in the North Pacific and the Arctic Ocean in Summer 1982-2017
}

\author{
Tomonori Azumaya ${ }^{1}$ and Shigehiko Urawa ${ }^{2}$ \\ ${ }^{1}$ Hokkaido National Fisheries Research Institute Japan Fisheries Research and Education Agency, 116 Katsurakoi, \\ Kushiro, 085-0802, Japan \\ ${ }^{2}$ Hokkaido National Fisheries Research Institute Japan Fisheries Research and Education Agency, 2-2, Japan
}

Keywords: chum salmon, distribution area, North Pacific, Arctic Ocean

Chum salmon (Oncorhynchus keta) is widely distributed in the North Pacific Ocean and adjacent waters. The thermal limit of chum salmon habitats is between $2.7^{\circ} \mathrm{C}$ to $15.6^{\circ} \mathrm{C}$ (Azumaya et al. 2007). Azumaya et al. (2007), Kaeriyama (2008) and Kaeriyama et al. $(2012,2014)$ predicted a northward shift and decrease of the distribution area of chum salmon as a result of global warming. There is possible shift in the distribution area of chum salmon with recent warming of SST already. However, it is not clear how the distribution area of chum has changed from the past to the present. Thus, we examined the interannual change in the distribution area of chum salmon in the North Pacific and the Arctic Ocean from 1982 to 2017.

The area that was enclosed by the upper thermal limit $\left(15.6^{\circ} \mathrm{C}\right)$, the lower thermal limit $\left(2.7^{\circ} \mathrm{C}\right)$ was assumed as the acceptable habitat of chum salmon. The distribution area of chum salmon in July, August and September were estimated using the gridded SST from 1982 to 2017 . The SST data between $30^{\circ} \mathrm{N}$ and $75^{\circ} \mathrm{N}, 140^{\circ} \mathrm{E}$ and $120^{\circ} \mathrm{W}$ are based on NOAA High-resolution Blended Analysis of Daily SST Data Set (https://www.esrl.noaa.gov/psd/data/gridded/) and the resolution of SST data are 1/4 x 1/4 . Composite maps of the area of chum salmon distribution were constructed from the decadal average SST from 1982 to 1991 and 2008 to 2017.
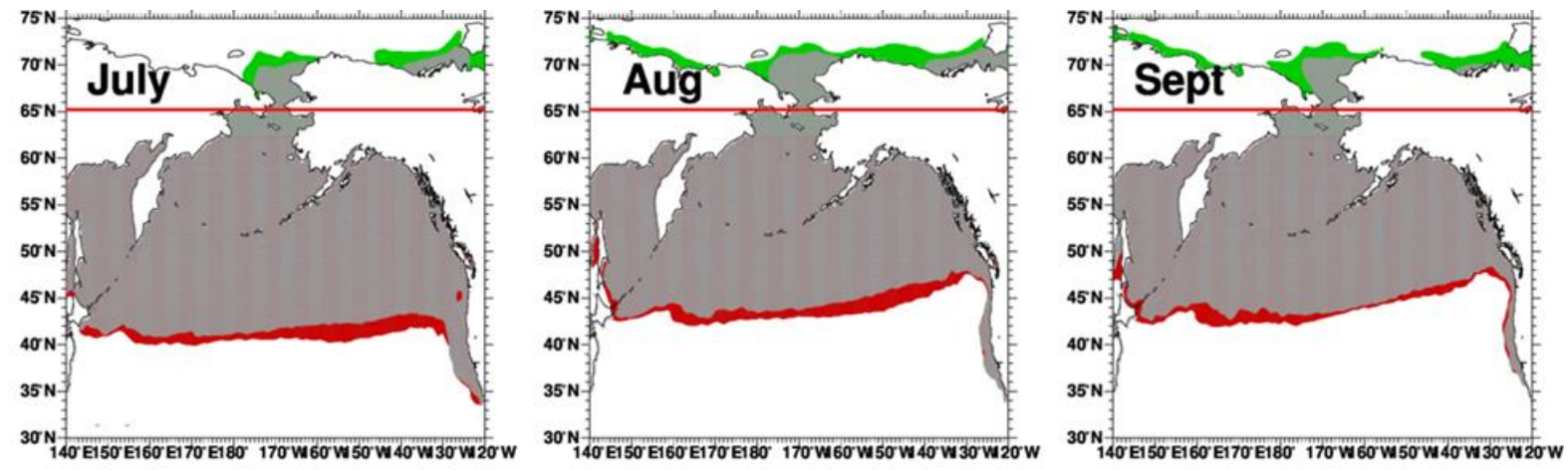

Fig. 1. Horizontal areas of chum salmon distribution. Gray shows the area of chum salmon distribution. Red and green show the difference between the area of decadal composite distribution from 1982 to 1991 and the area of decadal composite distribution from 2008 to 2017. Red (green) shows that the southern (northern) limit of chum salmon distribution has shifted northward for 36 years. The northern region of the horizontal red lines of $65^{\circ} \mathrm{N}$ was assumed as the Arctic Ocean.

Long-term trends of SST in the North Pacific and the Arctic Ocean in the summer of 1982-2017 were positive except for the US west coastal area in July to September and the western area of the Arctic Ocean in July. The southern and northern limit of chum salmon distribution has shifted northward. The area of chum salmon distribution in the North Pacific in summer has decreased approximately $860 \times 10^{3} \mathrm{~km}^{2}$ during the last 36 years (Fig. 1, Table 1). On the other hand, the area of chum salmon distribution in the Arctic Ocean has increased approximately $328 \times 10^{3} \mathrm{~km}^{2}$ (Table 1). The interannual change in area of chum salmon distribution in summer had a statistically significant negative trend $(p<0.01)$ which was about $-12 \times 10^{3} \mathrm{~km}^{2} \cdot \mathrm{year}^{-1}$ to $-27 \times 10^{3} \mathrm{~km}^{2} \cdot \mathrm{year}^{-1}$ (Table 2).

The distribution of chum salmon in both the North Pacific and the Arctic Ocean in summer has shifted northward and the area of chum salmon distribution has decreased approximately $5 \%\left(744 \times 10^{3} \mathrm{~km}^{2}\right)$ during the last 36 years. These changes may influence the carrying capacity during the ocean life of chum salmon. 
Table 1. The decadal composite area of chum salmon distribution in the North Pacific, the Arctic Ocean, and in both the Arctic Ocean and the North Pacific in summer $\left(\times 10^{3} \mathrm{~km}^{2}\right)$.

\begin{tabular}{lcccccc}
\hline & $\begin{array}{c}\text { July } \\
(1982-\end{array}$ & $\begin{array}{c}\text { July } \\
(2008-\end{array}$ & $\begin{array}{c}\text { Aug } \\
(1982-\end{array}$ & $\begin{array}{c}\text { Aug } \\
(2008-\end{array}$ & $\begin{array}{c}\text { Sept } \\
(1982-\end{array}$ & $\begin{array}{c}\text { Sept } \\
(2008-\end{array}$ \\
Regsion & $1991)$ & $2017)$ & $1991)$ & $2017)$ & $1991)$ & $2017)$ \\
\hline $\begin{array}{l}\text { North Pacific } \\
\left(30^{\circ} \mathrm{N}-65^{\circ} \mathrm{N}, 140^{\circ} \mathrm{E}-120^{\circ} \mathrm{W}\right)\end{array}$ & 13950 & 12966 & 11314 & 10360 & 11219 & 10476 \\
$\begin{array}{l}\text { Arctic Ocean } \\
\left(65^{\circ} \mathrm{N}-75^{\circ} \mathrm{N}, 140^{\circ} \mathrm{E}-120^{\circ} \mathrm{W}\right)\end{array}$ & 307 & 536 & 443 & 787 & 272 & 684 \\
$\begin{array}{l}\text { Arctic Ocean and North Pacific } \\
\left(30^{\circ} \mathrm{N}-75^{\circ} \mathrm{N}, 140^{\circ} \mathrm{E}-120^{\circ} \mathrm{W}\right)\end{array}$ & 14257 & 13502 & 11767 & 11147 & 11491 & 11160 \\
\hline
\end{tabular}

Table 2. Long-term trend of the area of chum salmon distribution in the North Pacific, the Arctic Ocean and in

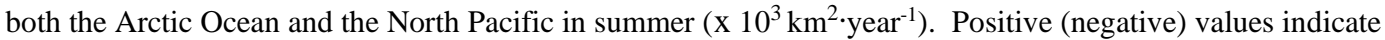
that the area of chum salmon distribution has increased (decreased) for 36 years.

\begin{tabular}{lccc}
\hline \multicolumn{1}{c}{ Region } & July & August & September \\
\hline $\begin{array}{l}\text { North Pacific } \\
\left(30^{\circ} \mathrm{N}-65^{\circ} \mathrm{N}, 140^{\circ} \mathrm{E}-120^{\circ} \mathrm{W}\right)\end{array}$ & -36 & -34 & -28 \\
$\begin{array}{l}\text { Arctic Ocean } \\
\left(65^{\circ} \mathrm{N}-75^{\circ} \mathrm{N}, 140^{\circ} \mathrm{E}-120^{\circ} \mathrm{W}\right)\end{array}$ & 9 & 12 & 16 \\
$\begin{array}{l}\text { Arctic Ocean and North Pacific } \\
\left(30^{\circ} \mathrm{N}-75^{\circ} \mathrm{N}, 140^{\circ} \mathrm{E}-120^{\circ} \mathrm{W}\right)\end{array}$ & -27 & -23 & -12 \\
\hline
\end{tabular}

\section{REFERENCES}

Azumaya, T., T. Nagasawa, O.S. Temnykh, and G.V. Khen. 2007. Regional and seasonal differences in temperature and salinity limitations of Pacific salmon (Oncorhynchus spp.). N. Pac. Anadr. Fish Comm. Bull. 4: 179-187. (Available at https://npafc.org)

Kaeriyama, M. 2008. Ecosystem-based sustainable conservation and management of Pacific salmon. In Fisheries for global welfare and environment. Edited by K. Tsukamoto, T. Kawamura, T. Takeuchi, TD. Beard Jr, MJ. Kaiser. TERRA-PUB, Tokyo. pp. 371-380.

Kaeriyama, M., H. Seo, and Y. Qui. 2014. Effect of global warming on the life history and population dynamics of Japanese chum salmon. Fish. Sci. 80: 251-260.

Kaeriyama, M., H. Seo, H. Kudo, and M. Nagata. 2012. Perspectives on wild and hatchery salmon interactions at sea, potential climate effects on Japanese chum salmon, and the need for sustainable salmon fishery management reform in Japan. Environ. Biol. Fish. 94: 165-177. 